\section{Antioxidant, enzyme-inhibitory and antitumor activity of the wild dietary plant Muscari comosum (L.) Mill.}

\author{
Teresa Casacchia, ${ }^{1}$ Adriano Sofo, ${ }^{2}$ \\ Ivan Casaburi, ${ }^{1}$ Mariangela Marrelli, ${ }^{1}$ \\ Filomena Conforti, ${ }^{1}$ Giancarlo A. Statti ${ }^{1}$ \\ ${ }^{1}$ Department of Pharmacy, Health and \\ Nutrition Sciences, University of \\ Calabria, Rende; ${ }^{2}$ School of \\ Agricultural, Forestry, Food and \\ Environmental Sciences, University \\ of Basilicata, Potenza, Italy
}

\begin{abstract}
Conventional medicines used to treat obesity and cancer frequently exhibit high side effects, so that researchers are focusing on new therapies and drugs based on natural products. Total extracts from bulbs of Muscari comosum were tested for i) free radical scavenging activity, ii) in vitro enzymatic inhibition of pancreatic $\alpha$-amylase and lipase, and iii) inhibition of the growth of breast adenocarcinoma cells. Three treatments were considered: bulbs boiled in water for $15 \mathrm{~min}$ (traditional cooking method; BB); bulbs steam-cooked for 15 min (alternative cooking method; SB); raw bulbs (RB). The polyphenol content and antioxidant capacity of bulb extracts were related to the inhibition of pancreatic lipase and $\alpha$-amylase, whose activities have been found to have a half maximal inhibitory concentration $\left(\mathrm{IC}_{50}\right)$ of $0.28,2.14$ and 3.22 $\mathrm{mg} / \mathrm{mL}$ for lipase, and $0.16,0.73$ and 0.69 $\mathrm{mg} / \mathrm{mL}$ for $\alpha$-amylase in $\mathrm{RB}, \mathrm{SB}$ and $\mathrm{BB}$, respectively. The analysis on breast adenocarcinoma MCF-7 cells revealed that $\mathrm{RB}$ extracts, and in a lesser extent BB, exerted a dose-dependent inhibition on cell proliferation. Considering that the potential of natural products for the treatment of obesity are under exploration, $M$. comosum could be an excellent plant for the development of future anti-obesity drugs, also able to prevent cancer.
\end{abstract}

\section{Introduction}

According to the World Health Organization, ${ }^{1}$ overweight and obesity are defined as abnormal or excessive fat accumulation that increases the risk of chronic metabolic diseases. Chronic inflammation, characterized by the hypersecretion of proinflammatory adipokines, that aggravates the production of reactive oxygen species (ROS), is a central characteristic of obesity. ${ }^{2}$ ROS are inevitably produced in biological systems due to oxidative metabolism, and are known to cause various degenerative disorders. ${ }^{3,4}$

Plant phenols are defense secondary metabolites produced by plants. They exert a ROS-scavenger activity but also have interesting biological activities related to enzymes inhibition, such as lipases and amylases. ${ }^{5}$ In this context, the dietary polyphenols have a potential as nutritional strategies for the prevention and treatment of obesity and cancer, and their associated inflammations. Indeed, these two diseases have often been associated to a reduced consumption of fruit and vegetables, containing phenols. ${ }^{6}$ Several studies have explored the relationship between overweight/obesity with an increased risk for cancer, mainly due to over-production of hormones, such as insulin or estrogen. ${ }^{7,8}$ Due to their ROS-scavenging and antioxidative action, plant phenols have a dosedependent inhibition on the growth and proliferation of cancer cells. ${ }^{9,10}$ One of the most important strategies in the treatment of obesity includes inhibitors of nutrient digestion in an attempt to reduce energy intake through pancreatic lipase and amylase inhibition. ${ }^{11,12}$ The lipase hydrolyzes a molecule of triglyceride in position 1 and 3 , releasing fatty acid and 2-monoglyceride. The inhibition of lipase prevents the release of fatty acids, and then promote the nonabsorption of fats. This inhibitory effect is has already been found for the anti-obesity drug Orlistat, containing tetrahydrolipstatin as active ingredient. On the other hand, pancreatic $\alpha$-amylase catalyzes the hydrolysis of 1,4- $\alpha$-D-glucosidic oligosaccharides and polysaccharides containing three or more residues, so yielding glucose and maltose, that enter glycolysis and, if in excess, are then converted in fats.

Interestingly, the effects of lipid-lowering, anti-obesity and anti-cancer plant extracts are becoming a sound topic in science research of food and nutrition. ${ }^{13,14} \mathrm{~A}$ variety of natural products, including crude extracts and pure isolated natural compounds containing phenolss can promote the reduction of adipose tissue mass and they have been widely used in the treatment of diet-induced obesity. ${ }^{15,16}$ Several authors studied phytochemical aspect related to phenols content in wild species traditionally consumed in the Mediterranean diet. ${ }^{17,18}$

In this study, we investigated a product of the culinary culture of the Mediterranean diet: cooked and raw bulbs of a wild onion species (Muscari comosum), commonly called lampascioni. The genus Muscari
Correspondence: Giancarlo A. Statti, Department of Pharmacy, Health and Nutrition Sciences, University of Calabria, via Pietro Bucci, 87036 Rende (CS), Italy.

Tel.: +39.0984.493063 - Fax: +39.0984.493298 E-mail: giancarlo.statti@unical.it

Key words: $\alpha$-amylase; antioxidant; cancer; Muscari comosum; pancreatic lipase; phenols.

Contributions: TC conducted the experiments about extraction, inhibition of amylase and antioxidant activity; AS conducted statistical analysis and interpretation of statistical data; IC conducted the experiments about cell proliferation; MM conducted the experiments about inhibition of lipase; FC collected test data and drafted the manuscript; GAS designed the study and interpreted the results.

Conflict of interest: the authors declare no conflict of interest.

Received for publication: 20 September 2016. Revision received: 24 October 2016.

Accepted for publication: 24 October 2016.

This work is licensed under a Creative Commons Attribution-NonCommercial 4.0 International License (CC BY-NC 4.0).

(C) Copyright T. Casacchia et al., 2017 Licensee PAGEPress srl, Italy

International Journal of Plant Biology 2017; 8:6895 doi:10.4081/pb.2017.6895

belongs to the family of Liliaceae and includes about 50 species manly distributed in Southern Italy, Greece, Turkey and Iran. ${ }^{19,20}$ Particularly, M. comosum has been studied for its peculiar organoleptic, ${ }^{21,22}$ economic, ${ }^{23}$ and antioxidant characteristics, ${ }^{24}$ but its pharmaceutical properties are mostly unknown. For this purpose, bulbs of lampascioni were screened for their content in total polyphenols and flavonoids, and tested for antioxidant properties, inhibiting activity of pancreatic lipase and $\alpha$-amylase and antiproliferative activity against human cancer cells.

\section{Materials and Methods \\ Plant material and preparation of samples}

Bulbs of Muscari comosum were collected in field in Paludi (39 $31^{\prime} 12.91^{\prime} \mathrm{N}$, $16^{\circ} 41^{\prime} 41.95^{\prime \prime} \mathrm{E} \quad$ - $\quad 39^{\circ} 31^{\prime} 9.23^{\prime \prime} \mathrm{N}$; $16^{\circ} 41$ '47.13'”) (Cosenza district, Calabria Region, Italy) during July 2015. The bulbs were stored in a cool and dry environment and subsequently were deprived of the roots and soil residues. Three treatments were 
considered: bulbs boiled in water for $15 \mathrm{~min}$ (traditional cooking method; BB); bulbs steam-cooked for 15 min (alternative cooking method; SB); raw bulbs (RB). Each sample was extracted through Naviglio ${ }^{\circledR}$ extractor (Atlas Filtri S.r.L., Limena, PD, Italy) for $36 \mathrm{~h}$ at $20^{\circ} \mathrm{C}$ and high pressure ( 8 bar), using two cycles with $2 \mathrm{~L}$ ethanol each. The average extraction yield (fresh sample/ethanol) was $21 \%$. Solvent was evaporated using a Rotavapor ${ }^{\circledR}$ R-220 SE (BÜCHI Labortechnik AG, Flawil, Switzerland).

\section{Determination of total phenol compounds}

Total phenol content of the total extracts was determined using Folin-Ciocalteu reagent and chlorogenic acid as standard. ${ }^{25}$ A 20-mg aliquot of the extracts was vortexed with $25 \mathrm{~mL}$ of the extraction solvent (95:5, water: $37 \% \mathrm{HCl})$. during the tests, we compared absorbance of the extract with different methods. We verified that the absorbance values changed in the various tests. We thus tested strong acid at different concentrations $(1 \%, 2 \%, 3 \%$ up to $5 \%)$. In fact, in this last concentration of $\mathrm{HCl}$ the result on the determination of the polyphenols has stabilized. We decided to use $\mathrm{H} 2 \mathrm{O}$ : $\mathrm{HCl}$ the 5:95 ratio. Then, the samples were heated at $60^{\circ} \mathrm{C}$ (water bath) for $1 \mathrm{~h}$, allowed to cool to room temperature, and finally homogenized. An amount of $200 \mu \mathrm{L}$ (three replicates) was introduced into screw cap test tubes. Then, $1.0 \mathrm{~mL}$ of Folin-Ciocalteu reagent and, after $3 \mathrm{~min}, 1.0 \mathrm{~mL}$ of $\mathrm{Na}_{2} \mathrm{CO}_{3}$ $(7.5 \%)$ were added. The tubes were vortexed and heated at $40^{\circ} \mathrm{C}$ (water bath) for 30 min. The calibration curve was determined with seven standards with concentrations ranging from 50 to $1200 \mu \mathrm{g} / \mathrm{mL}$. The absorption at $726 \mathrm{~nm}$ was measured (Perkin-Elmer Lambda 40 UV/VIS spectrophotometer) and the total phenol content expressed as mg of chlorogenic acid equivalents (CAE) per $g$ of fresh material (FW).

\section{Determination of total flavonoids}

The total flavonoid content of crude extract was determined on the same extracts used for total phenols determination by the $\mathrm{AlCl}_{3}$ colorimetric method. ${ }^{26} \mathrm{In}$ brief, $1 \mathrm{~mL}$ of $\mathrm{EtOH}$ was added to $2 \mathrm{mg}$ of crude extract. After $5 \mathrm{~min}$ of incubation, $1 \mathrm{~mL}$ di $2 \% \mathrm{AlCl}_{3}$ aqueos solution was added and the mixture was allowed to stand for 15 min. The calibration curve was determined with eight standard concentrations, ranging from 25 to $900 \mu \mathrm{g} / \mathrm{mL}$. The absorbance was measured at $430 \mathrm{~nm}$. Total flavonoid content was expressed as mg quercetin equivalent $(\mathrm{QE})$ per $\mathrm{g}$ of fresh material (FW).

\section{Antioxidant properties}

The 1,1-diphenyl-2-picryl-hydrazyl (DPPH) assay was adapted from Marrelli and others. ${ }^{25}$ In an ethanol solution of 1,1diphenyl-2-picrylhydrazyl (DPPH) radical (final concentration $=1.0 \times 10^{-4} \mathrm{M}$ ), extracts at different concentrations were added. The reaction mixtures were shaken vigorously and then kept in the dark for $30 \mathrm{~min}$. The absorbance of the resulting solutions was measured at $517 \mathrm{~nm}$, against a blank with DPPH. Decreasing absorbance values of the DPPH solutions indicated an increase of DPPH radical scavenging activity. The DPPH solution without sample solution was used as control. Ascorbic acid was used as positive control.

This activity was given as \% DPPH radical scavenging, calculated by the following equation:

\section{$\%$ DPPH radical scavenging $=$}

(absorbance control - absorbance sample)/ absorbance control $\times 100$.

For the realization of the $\beta$-carotene bleaching method (BCB) method, ${ }^{25} 2 \mathrm{~mL}$ of a $\beta$-carotene $0.5 \mathrm{mg} / \mathrm{mL}$ solution in chloroform are added to $0.04 \mathrm{~mL}$ of linoleic acid and $0.4 \mathrm{~mL}$ of Tween 20 . The mixture was then evaporated at $40^{\circ} \mathrm{C}$ for $10 \mathrm{~min}$ through a rotary evaporator, in order to remove the chloroform, and immediately diluted with $150 \mathrm{~mL}$ of distilled water. Water was slowly added to the mixture and vigorously stirred to form an emulsion. Them, $5 \mathrm{~mL}$ of the emulsion were added to $0.2 \mathrm{~mL}$ of samples at different concentrations $(100,50,25,10$, $5,1 \mathrm{mg} / \mathrm{mL}$ ). The tubes were stirred slowly and kept at $45^{\circ} \mathrm{C}$ in a water bath. The absorbance was read at a wavelength of 470 $\mathrm{nm}$ at an initial time $(t=0)$ and subsequently at $30 \mathrm{~min}$. The antioxidant activity (AA) was measured using the following equation.

$$
\mathrm{AA}=\left[1-\left(\mathrm{A}_{0}-\mathrm{A}_{\mathrm{t}}\right) /\left(\mathrm{A}_{0}^{\mathrm{o}}-\mathrm{A}_{\mathrm{t}}^{\mathrm{o}}\right)\right] \times 100
$$

where $\mathrm{A}_{0}$ and $\mathrm{A}_{0}^{\circ}$ are the absorbance values measured at the initial incubation time for samples/standard and control, respectively, while $\mathrm{A}_{\mathrm{t}}$ and $\mathrm{A}^{\circ}{ }_{\mathrm{t}}$ are the absorbance values measure in the samples/standard and control at $\mathrm{t}=30 \mathrm{~min}$, respectively.

\section{Determination of pancreatic lipase activity}

A water solution $(3 \mathrm{mg} / \mathrm{mL})$ was prepared from type II crude porcine pancreatic. ${ }^{27}$ Then a $7.5 \mathrm{mmol} / \mathrm{L}$ solution of 4-nitrophenyl octanoate (NPO) in dimethyl sulfoxide was prepared. The composition of the reaction mixture was the following: 100 $\mu \mathrm{L}$ of $7.5 \mathrm{mmol} / \mathrm{L} \mathrm{NPO}, 4 \mathrm{~mL}$ of Tris- $\mathrm{HCl}$ buffer $(\mathrm{pH}=8.5), 100 \mu \mathrm{L}$ of extract (concentration 430, 215, 107.5, 57.33, 23.60, $12.5,5,2.5,1,0.5,0.25,0.065 \mathrm{mg} / \mathrm{mL}$ ) and $100 \mu \mathrm{L}$ of enzyme solution. The mixture was incubated at $37^{\circ} \mathrm{C}$. In the control, the extract was replaced with the same volume of dimethyl sulfoxide (DMSO). The absorbance was measured at $412 \mathrm{~nm}$. A blank sample without the enzyme was prepared for each extract. Orlistat was used for comparison.

\section{Determination of pancreatic $\alpha$-amy- lase activity}

The inhibition of the enzyme $\alpha$-amylase was evaluated using a modified version of the method of Kwon and others. ${ }^{28}$ An amount of $100 \mu \mathrm{L}$ of a solution of the sample (concentration 430, 215, 57.33, 12.5, 5, 2, 1.36, 0.32, 0.16, $0.08 \mathrm{mg} / \mathrm{mL}$ ) was added to $500 \mu \mathrm{L}$ of $0.5 \mathrm{mg} / \mathrm{mL}$ enzyme solution in cold distilled water and to $500 \mathrm{~L}$ of $1 \%$ $(\mathrm{w} / \mathrm{v})$ starch solution in $0.01 \mathrm{M}$ phosphate buffer at $\mathrm{pH}$ 7.0. The reaction mixture was incubated at $37^{\circ} \mathrm{C}$ for $5 \mathrm{~min}$; the reaction was stopped after the addition of $1 \mathrm{~mL}$ of the reagent dye DNS (3,5-dinitrosalicylic acid and $1 \%$ potassium sodium tartrate in $2 \% \mathrm{NaOH} 0.4 \mathrm{M}$ ). The reaction mixture was incubated at $100^{\circ} \mathrm{C}$ for $5 \mathrm{~min}$ and the absorbance measured at $540 \mathrm{~nm}$.

\section{Cell culture and MTT assay}

Human breast adenocarcinoma (MCF7) cell line were obtained from the nonprofit association American Type Culture Collection (ATCC, Manassas, Virginia, USA). Cells were grown in Dulbecco's modified Eagle's medium (DMEM) supplemented with $10 \%$ fetal bovine serum (FBS) (Gibco BRL, San Francisco, CA, USA) at $37^{\circ} \mathrm{C}$ in a humid atmosphere containing $5 \%$ $\mathrm{CO}_{2}$. Raw (RB) or boiled (BB) bulb extracts were dissolved in DMSO and further diluted in DMEM without FBS to obtain the desired final concentrations $(1,10,50,100$, 200, 400 and $800 \mu \mathrm{g} / \mathrm{mL})$. Appropriate controls (vehicle) containing $0.5 \%$ DMSO were performed. MCF-7 cells were seeded in 48well plates at a density of $20 \times 10^{3}$ cells well $^{-1}$ and cultured in complete medium overnight. Before treatment, culture medium was switched into DMEM F-12 supplemented with $1 \%$ FBS and cells were untreated (vehicle) or treated with different concentrations of raw or cooked bulb extracts for $72 \mathrm{~h}$. DMSO was used as vehicle control. Cell viability was measured using MTT (3-(4,5-dimethylthiazol-2-yl)2,5-diphenyltetrazolium bromide) assay (Sigma-Aldrich, St. Louis, MO, USA). The optical density was measured spectrophotometrically at $570 \mathrm{~nm}$. 


\section{Statistical analysis}

Data were analyzed using SPSS r.11.0.0 statistical software (SPSS, Inc., Chicago, IL, USA). All measurements were carried out in replicates $(n=3)$. Significant differences were calculated at $\mathrm{P} \leq 0.05$ level among means by one-way ANOVA, using Tukey's test.

The values of $\mathrm{IC}_{50}$ (half maximal inhibitory concentration) for each measured parameter was calculated by means of scatter charts (where the $\mathrm{X}$-axis indicates the concentration and the $\mathrm{Y}$ axis is the $\%$ activity or $\%$ inhibition). Trend lines were plotted and $\mathrm{IC}_{50}$ calculated by a linear trendline $(\mathrm{Y}=\mathrm{a} \mathrm{X}+\mathrm{b})$ by the formula $\mathrm{IC}_{50}=(0.5-$ b) / a.

\section{Results and Discussion}

Total phenol and flavonoid contents

Polyphenols are a class of naturallyoccurring phytochemicals that have been shown to modulate physiological and molecular pathways that are involved in energy metabolism, adiposity, and obesity. ${ }^{29}$ These compounds have redox properties, which allow them to act as antioxidants. ${ }^{11,17,18}$ As their ROS-scavenging ability is facilitated by their hydroxyl groups, the total phenol concentration is used as a basis for a screening of antioxidant activity. Our results show that the total phenol content in bulb extracts was $92.47 \pm 0.020$, $49.80 \pm 0.012$, and $39.53 \pm 0.027 \mathrm{mg}$ chlorogenic acid equivalents (CAE) per $\mathrm{g} \mathrm{FW}$ in $\mathrm{RB}, \mathrm{SB}$ and $\mathrm{BB}$, respectively (Table 1). The total polyphenol content of $M$. comosum is particularly high enough, compared to other plant species, to justify its important antioxidant activity observed. ${ }^{24}$ From a nutritional point of view, it is interesting to observe how the polyphenols content decreased significantly after a normal cooking operation. In fact, in the cooked bulbs, the total polyphenols content was significantly reduced ( -46 and $-47 \%$ in $\mathrm{SB}$ and $\mathrm{BB}$, compared to RB).

Among phenols, flavonoids, including flavones, flavanols and condensed tannins, are important plant secondary metabolites, the antioxidant activity of which depends on the presence of free hydroxyl groups, especially those at the $\mathrm{C} 3$ position. In our experiment, the values of total flavonoid content were $4.57 \pm 0.003,1.63 \pm 0.010$, and $0.635 \pm 0.026 \mathrm{mg}$ quercetin equivalents (QE) per $\mathrm{g}$ in $\mathrm{RB}, \mathrm{SB}$ and $\mathrm{BB}$, respectively (Table 1). Total flavonoids appeared to be about $5 \%$ of the total polyphenols in RB and their value and this proportion significantly decreased after cooking ( 3 and $2 \%$ of total polyphenols in $\mathrm{SB}$ and $\mathrm{RB}$, respectively).

\section{Antioxidant activity}

Plants are rich in secondary metabolites, including phenols, flavonoids and carotenoids, which have antioxidant activity due to their redox properties and chemical structures. Particularly, Muscari spp. has been demonstrated to have a strong antioxidant activity and a high phenol content. ${ }^{24}$ It was also demonstrated that chemical constituents of Muscari spp. are homoisoflavonoids, that confer a strong antioxidant capacity and have antimutagenic properties. ${ }^{30}$

The effect of antioxidants on the scavenging activity of DPPH radical is due to their hydrogen-donating ability, with the reduction of the stable free radical DPPH to the yellow-colored 1,1-diphenyl-2-picrylhydrazyl free radical. This method offers the first approach for evaluating the antioxidant potential of a compound, an extract or other biological sources. The highest free radical scavenging activity (DPPH) was exerted by $\mathrm{RB}$, with an $\mathrm{IC}_{50}=1.34 \pm 0.19$ $\mathrm{mg} / \mathrm{mL} \quad\left(r^{2}=0.992\right)$ followed by $\mathrm{SB}$ $\left(\mathrm{IC}_{50}=3.5880 \pm 0.09 \mathrm{mg} / \mathrm{mL} ; r^{2}=0.982\right)$ and $\mathrm{BB} \quad\left(\mathrm{IC}_{50}=9.63 \pm 0.04 \mathrm{mg} / \mathrm{mL} ; r^{2}=0.978\right)$. Moreover, a significant correlation was observed between phenol content and the scavenging of DPPH radical in raw bulbs $\left(r^{2}=0.991, \mathrm{P}<0.5\right)$, indicating that the radi- cal scavenging capacity of the extracts could be related to the concentration of phenol compounds.

The results on lipid peroxidation inhibitory activity of the bulbs of $M$. comosum, assessed by the $\beta$-carotene bleaching (BCB) test are shown in Table 2. This method is based on the loss of the yellow color of $\beta$-carotene due to its reaction with radicals which are produced by linoleic acid oxidation (inhibition of lipid peroxidation), the addition to the reaction mixture $(\beta$ carotene + linoleic acid) of an antioxidant inhibits the oxidation of $\beta$-carotene. The results obtained from $\mathrm{BCB}$ assay are similar to the data obtained from DPPH test, indeed raw bulbs presented a higher antioxidant activity $\left(\mathrm{IC}_{50}=9.13 \pm 1.31 \mathrm{mg} / \mathrm{mL} ; r^{2}=0.917\right)$ compared to the cooked ones $\left(\mathrm{IC}_{50}=17.37 \pm 0.91\right.$ and $14.81 \pm 1.14 \mathrm{mg} / \mathrm{mL}$ in $\mathrm{SB}$ and $\mathrm{BB}$, with $r^{2}=0.985$ and 0.980 , respectively).

\section{Inhibition of lipase and $\alpha$-amylase activities}

The management of obesity and prevention of diseases related to diet is nowadays, in the clinical, an ordinary activity required for containing public spending and reducing the consumption of drugs paid by the national health systems. Increasing the

Table 1. Total polyphenol and flavonoid content and antioxidant activity evaluated by ascorbic acid method of extracts of raw and cooked lampascioni (Muscari comosum).

\begin{tabular}{lccc} 
Theatment & $\begin{array}{c}\text { Total polyphenols } \\
(\mathrm{mg} \mathrm{CAE} / \mathrm{g} \mathrm{FW})\end{array}$ & $\begin{array}{c}\text { Total flavonoids } \\
(\mathrm{mg} \mathrm{OE} / \mathrm{g} \mathrm{FW})\end{array}$ & $\begin{array}{c}\text { DPPH }\left(\mathrm{IC}_{50}\right)^{\mathrm{a}} \\
(\mathrm{mg} / \mathrm{mL})\end{array}$ \\
Raw bulbs & $92.47 \pm 0.020^{\mathrm{a}}$ & $4.57 \pm 0.003^{\mathrm{a}}$ & $1.34 \pm 0.19^{\mathrm{c}}$ \\
Steamed bulbs & $49.80 \pm 0.012^{\mathrm{b}}$ & $1.63 \pm 0.010^{\mathrm{b}}$ & $3.59 \pm 0.09^{\mathrm{b}}$ \\
\hline Boiled bulbs & $39.53 \pm 0.027^{\mathrm{c}}$ & $0.64 \pm 0.026^{\mathrm{c}}$ & $9.63 \pm 0.04^{\mathrm{a}}$ \\
\hline
\end{tabular}

Total phenolics are expressed as chlorogenic acid equivalents (CAE) per $\mathrm{g}$ of fresh material (FW). Total flavonoids are expressed as quercetin equivalents (QE) per $\mathrm{g}$ of fresh material (FW). Means ( $\mathrm{n}=3) \pm \mathrm{SD}$ with different letters within the same column are significantly different at $\mathrm{P}<0.05$. Positive reference DPPH: ascorbic acid.

Table 2. Antioxidant activity evaluated by $\beta$-carotene bleaching method of extracts of raw and cooked lampascioni (Muscari comosum).

\begin{tabular}{lccc} 
Treatment & Concentration $(\mathrm{mg} / \mathrm{mL})$ & Inhibition $(\%)$ & $\mathrm{IC}_{50}(\mathrm{mg} / \mathrm{mL})$ \\
Raw bulbs & 25 & $100.00 \pm 0.01$ & $9.13 \pm 1.31^{\mathrm{b}}$ \\
& 10 & $65.41 \pm 0.08$ & \\
5 & $45.59 \pm 0.71$ & \\
& 1 & $17.06 \pm 1.14$ & \\
Steamed bulbs & 0.5 & $7.21 \pm 0.06$ & $17.37 \pm 0.91^{\mathrm{a}}$ \\
& 25 & $83.26 \pm 0.72$ & \\
& 10 & $41.05 \pm 0.02$ & $14.81 \pm 1.14^{\mathrm{a}}$ \\
& 5 & $13.73 \pm 1.52$ & \\
\hline Boiled bulbs & 1 & $0.22 \pm 0.01$ & \\
& 25 & $71.12 \pm 1.20$ & \\
& 10 & $34.02 \pm 0.93$ & \\
& 5 & $11.27 \pm 0.06$ & \\
& 0.5 & $0.08 \pm 0.01$ & \\
\hline
\end{tabular}

Means ( $\mathrm{n}=3) \pm \mathrm{SD}$ with different letters within the same column are significantly different at $\mathrm{P}<0.05$. 
prevalence of obesity and type 2 diabetes mellitus and the negative clinical outcomes observed with the commercially available anti-diabetic and anti-lipolytic drugs have led to the investigation of new therapeutic approaches focused on controlling postprandial lipid absorption and glucose levels. At this purpose, inhibition of lipid- and carbohydrate-hydrolyzing enzymes is so an emerging and useful tool.

Several natural products extract can provide a vast pool of pancreatic lipase inhibitors that can possibly be developed into clinical products. In our experiment, raw bulb extracts showed a significant inhibitory action on pancreatic lipase. The lipase inhibitory effects were indicated by the $\mathrm{IC}_{50}$ values of $0.28 \pm 0.07 \quad\left(r^{2}=0.912\right)$, $2.14 \pm 0.01 \quad\left(r^{2}=0.966\right), \quad$ and $3.22 \pm 0.03$ $\left(r^{2}=0.989\right) \mathrm{mg} / \mathrm{mL}$ in $\mathrm{RB}, \mathrm{SB}$ and $\mathrm{BB}$, respectively (Table 3 ).

The inhibition of $\alpha$-amylase by bulb extracts also showed significant differences among cooking methods, with $\mathrm{IC}_{50}$ values of $\quad 0.16 \pm 0.03 \quad\left(r^{2}=0.939\right), \quad 0.73 \pm 0.13$ $\left(r^{2}=0.984\right), \quad$ and $0.69 \pm 0.02 \quad\left(r^{2}=0.980\right)$ $\mathrm{mg} / \mathrm{mL}$ in $\mathrm{RB}, \mathrm{SB}$ and $\mathrm{BB}$, respectively (Table 4). These findings highlighted the importance of $M$. comosum in a diet rich of carbohydrates, as bulb extracts could reduce glucose absorbance, which in turn affects blood sugar levels.

\section{Inhibition of the growth of breast adenocarcinoma cells}

The analysis of the effects of different concentrations of raw or cooked bulb extracts on breast adenocarcinoma MCF-7 cells growth by MTT (3-(4,5-dimethylthiazol-2-yl)-2,5-diphenyltetrazolium bromide) assay revealed that treatment with raw bulb extracts exerted a dose-dependent inhibition on MCF-7 cell proliferation compared to vehicle-treated cells (Figure 1). By contrast, cooked bulb extracts also reduced MCF-7 cells viability but only at higher concentration (Figure 1). These results clearly indicate that cooking practice clearly influence the anti-proliferative effect of $M$. comosum, lowering their efficacy. This consideration is also supported by the clear difference between the $\mathrm{IC}_{50}$ value of raw bulb extracts (10.27 $\mu \mathrm{g} / \mathrm{mL} ; 95 \%$ interval confidence: 9.214-11.25 $\mu \mathrm{g} / \mathrm{mL})$, respect to that of cooked extracts $(669.3 \mu \mathrm{g} / \mathrm{mL}, 95 \%$ interval confidence: $517.6-865.6 \mu \mathrm{g} / \mathrm{mL})$.

\section{Conclusions}

The antioxidant activity and the inhibitory activity of pancreatic lipase and $\alpha$-amylase of the wild onion lampascioni

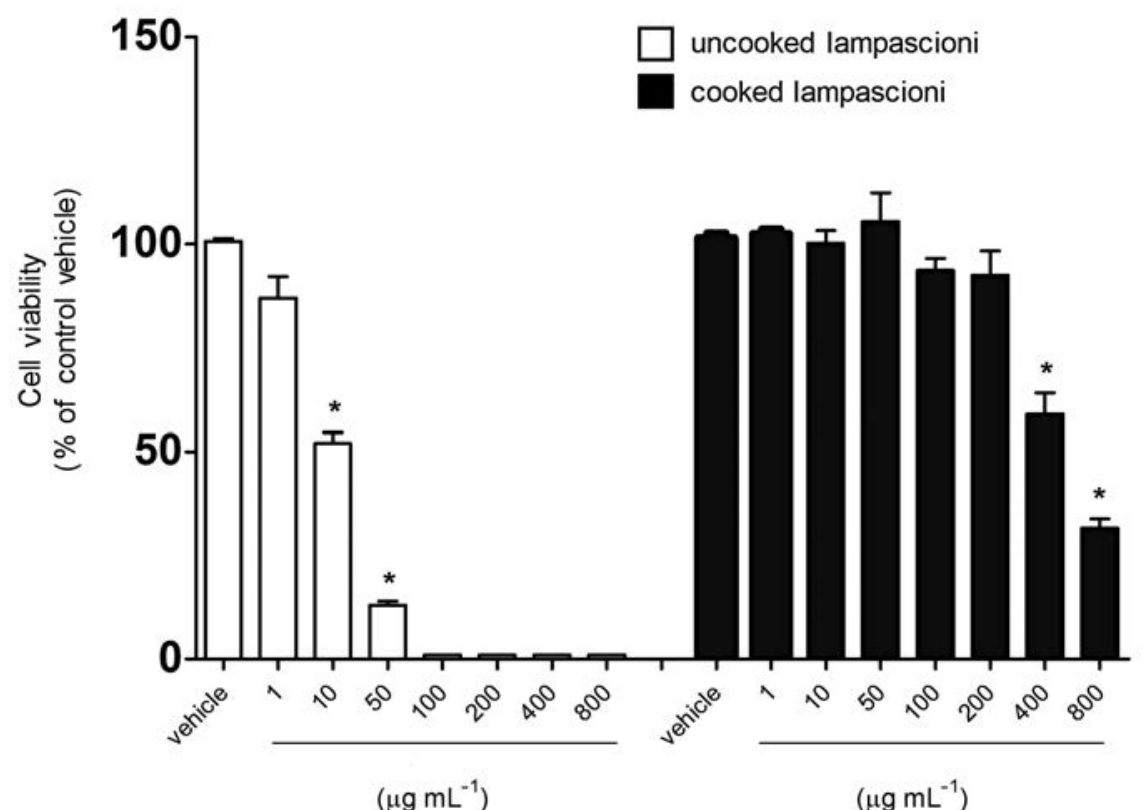

Extract concentration

Figure 1. Cell viability of tumoral MCF-7 cells treated of extracts of raw and cooked (boiled) lampascioni (Muscari comosum). Asterisks indicate significantly difference at $\mathrm{P}<0.05$, compared to the control (vehicle).

Table 3. Lipase inhibitory activity of extracts of raw and cooked lampascioni (Muscari comosum).

\begin{tabular}{lccc} 
Treatment & Concentration $(\mathrm{mg} / \mathrm{mL})$ & Inhibition $(\%)$ & $\mathrm{IC}_{50}(\mathrm{mg} / \mathrm{mL})$ \\
Raw bulbs & 1 & $99.62 \pm 1.12$ & $0.28 \pm 0.07^{\mathrm{c}}$ \\
& 0.25 & $58.82 \pm 1.09$ & \\
Steamed bulbs & 0.065 & $21.79 \pm 1.11$ & $2.14 \pm 0.01^{\mathrm{b}}$ \\
& 5 & $91.80 \pm 0.09$ & \\
\hline Boiled bulbs & 2.5 & $24.75 \pm 1.23$ & $3.22 \pm 0.03^{\mathrm{a}}$ \\
& 0.5 & $0.92 \pm 1.21$ & \\
\hline
\end{tabular}

Orlistat $\mathrm{IC}_{50}$ (positive control) $=0.082 \mathrm{mg} / \mathrm{mL}$. Means $(n=3) \pm \mathrm{SD}$ with different letters within the same column are significantly different at $\mathrm{P}<0.05$.

Table 4. $\alpha$-amylase inhibitory activity of extracts of raw and cooked lampascioni (Muscari comosum).

\begin{tabular}{lccc} 
Treatment & Extract concentration $(\mathrm{mg} / \mathrm{mL})$ & Inhibition $(\%)$ & $\mathrm{IC}_{50}(\mathrm{mg} / \mathrm{mL})$ \\
Raw bulbs & 0.32 & $93.52 \pm 0.12$ & $0.16 \pm 0.03 \mathrm{~b}$ \\
& 0.21 & $82.75 \pm 1.00$ & \\
Steamed bulbs & 0.07 & $23.60 \pm 1.31$ & \\
& 1.36 & $87.97 \pm 0.05$ & $0.73 \pm 0.13 \mathrm{a}$ \\
& 0.32 & $24.35 \pm 0.23$ & \\
\hline Boiled bulbs & 0.16 & $9.16 \pm 1.81$ & $0.69 \pm 0.02 \mathrm{a}$ \\
& 1.36 & $93.48 \pm 1.11$ & \\
\hline
\end{tabular}

Means $(\mathrm{n}=3) \pm \mathrm{SD}$ with different letters within the same column are significantly different at $\mathrm{P}<0.05$. 
(M. comosum) can increase antioxidant defenses, and at the same time reduce the absorption of fats and carbohydrates (Tables 1-4). These phytochemical components were closely related to the antitumor activity against breast adenocarcinoma cells. This study also demonstrated that the action of bioactive components of "lampascioni" extracts decreases as a function of the cooking mode, being both lower in the cooked bulbs. This means that traditional cooking can partially deplete food biological properties, compared to the raw product.

Prevention is a more effective strategy than treatment of chronic diseases. This wild dietary plant could be an excellent source of compound that can regulate the absorption of fats and sugars, so being useful for the control of obesity and some of the risk factors of the cardio-metabolic syndrome associated with obesity. The use of raw $M$. comosum, presenting higher biological activities than the cooked bulbs, is to be associated to its transformation into food supplement. Considering that the potential of natural products for the treatment of obesity are under exploration, M. comosum could be an excellent plant for the development of future effective, safe, anti-obesity drugs, also able to prevent cancer.

\section{References}

1. WHO. World Health Organization global health risks: mortality and burden of disease attributable to selected major risks. GENEVA: WHO; 2009.

2. Trostchansky A, Quijano C, Yadav H, et al. Interplay between Oxidative Stress and Metabolism in Signalling and Disease. Hindawi Publishing Corporation Oxidative Medicine and Cellular Longevity. 2016, Article ID 3274296, 2 pages.

3. Deng T, Lyon CJ, Bergin S, et al. Obesity, inflammation, and cancer. Annu Rev Pathol 2016;11:421-49.

4. Khan S, Jain M, Mathur V, Feroz SM. Chronic inflammation and cancer: paradigm on tumor progression, metastasis and therapeutic intervention. Gulf $\mathrm{J}$ Oncol 2016;1:86-93.

5. Rohn S, Rawel HM, Kroll J. Inhibitory effects of plant phenols on the activity of selected enzymes. J Agric Food Chem 2002;50:3566-71.

6. Liu RH. Health benefits of fruit and vegetables are from additive and synergistic combinations of phytochemicals.
Am J Clin Nutr 2003;78:517S-520S.

7. Cleveland RJ, Eng SM, Abrahamson $\mathrm{PE}$, et al. Weight gain prior to diagnosis and survival from breast cancer. Cancer Epidemiol Biomarkers Prev 2007;16: 1803-11.

8. Zhang X, Wu WKK, Yu J. Obesity and cancer. Chapter Obesity. 2016, 211-220.

9. Abrahim NN, Kanthimathi MS, AbdulAziz A. Piper betle shows antioxidant activities, inhibits MCF-7 cell proliferation and increases activities of catalase and superoxide dismutase BMC Complement. Altern Med 2012;12:220.

10. Mileo AM, Miccadei S. Polyphenols as Modulator of Oxidative Stress in Cancer Disease: New Therapeutic Strategies. Oxidative Medicine and Cellular Longevity. 2012, Article ID 6475624, 17 pages. http://dx.doi.org/10. 1155/2016/6475624).

11. Marrelli M, Loizzo MR, Nicoletti M, et al. In vitro investigation of the potential health benefits of wild Mediterranean dietary plants as anti-obesity agents with $\alpha$-amylase and pancreatic lipase inhibitory activities. J Sci Food Agr 2014;94:2217-24.

12. Pare D, Hilou A, Ouedraogo N, Guenne S. Ethnobotanical study of medicinal plants used as anti-obesity remedies in the nomad and hunter communities of Burkina Faso. Medicines 2016;3:9.

13. Bhutani KK, Birari RB, Kapat K. Potential anti-obesity and lipid lowering natural products; a review. Nat Prod Commun 2007;2:331-48.

14. Tundis R, Loizzo MR, Menichini F. Natural products as $\alpha$-amylase and $\alpha$ glucosidase inhibitors and their hypoglycaemic potential in the treatment of diabetes: an update. Mini Rev Med Chem 2010;10:315-31.

15. Santos AP, Rogero MM, Bastos DH. Edible plants, their secondary metabolites and antiobesogenic potential. Rec Pat Food Nutr Agric 2010;2:195-212.

16. Solowey E, Lichtenstein M, Sallon S, et al. Evaluating medicinal plants for anticancer activity. Sci Wrld J. 2014, Article ID 721402 .

17. Conforti F, Sosa S, Marrelli M, et al. The protective ability of Mediterranean dietary plants against the oxidative damage: the role of radical oxygen species in inflammation and the polyphenol, flavonoid and sterol contents. J Ethnopharmacol 2008;116:14451.

18. Morales P, Ferreira ICFR, Carvalho AM, et al. Mediterranean non-cultivat- ed vegetables as dietary sources of compounds with antioxidant and biological activity. LWT-Food Sci Technol 2014; 5:389-96.

19. Brian M. The smaller bulbs. London: B.T. Batsford; 1987.

20. Pieroni A, Nebel S, Quave C, et al. Ethnopharmacology of liakra: traditional weedy vegetables of the Arbëreshë of the Vulture area in southern Italy. J Ethnopharmacol 2002:81:165-85.

21. Borgonovo G, Caimia S, Morini G, et al. Taste-active compounds in a traditional italian food: "lampascioni". Chem Biodiv 2008;5:1184-94.

22. Renna M, Rinaldi VA, Gonnella M. The Mediterranean Diet between traditional food sand human health: the culinary example of Puglia (Southern Italy). Int J Gastron Food Sci 2015;2:63-1.

23. Casoria P, Menale B, Muoio R. Muscari comosum, Liliaceae, in the food habits of South Italy. Econ Botany 1999;53: 113-5.

24. Pieroni A, Janiak V, Dfrr CM, et al. In vitro antioxidant activity of non-cultivated vegetables of ethnic Albanians in Southern Italy. Phytother Res 2002;16: 467.

25. Marrelli M, Conforti F, Toniolo C, et al. Hypericum perforatum: influences of the habitat on chemical composition, photo-induced cytotoxicity, and antiradical activity. Pharm Biol 2014;52:90918.

26. Marrelli M, Cristaldi B, Menichini F, Conforti F. Inhibitory effects of wild dietary plants on lipid peroxidation and on the proliferation of human cancer cells. Food Chem Toxicol 2015;86:1624.

27. Conforti F, Perri V, Menichini F, et al. Wild Mediterranean dietary plants as inhibitors of pancreatic lipase. Phytother Res 2012;26:600-4.

28. Kwon YI, Apostolidis E, Kim YC, Shetty K. Health benefits of traditional corn, beans and pumpkin: In vitro studies for hyperglycemia and hypertension management. J Med Food 2007;10:26675.

29. Meydani M, Hasan ST. Dietary polyphenols and obesity. Nutrients 2010;2:737-51.

30. Miadokova E, Masterova I, Vickova V, et al. Antimutagenic potential of homoisoflavonoids from Muscari racemosum. J Ethnopharmacol 2002;81: 381. 